\begin{tabular}{|c|l|}
\hline Title & THE WELFARE GAINS FROM INTERNATIONAL MIGRATION \\
\hline Sub Title & \\
\hline Author & KEMP, Murray C. \\
\hline Publisher & Keio Economic Society, Keio University \\
\hline Publication year & 1993 \\
\hline Jtitle & Keio economic studies Vol.30, No.1 (1993. ) ,p.1- 5 \\
\hline JaLC DOI & \multicolumn{1}{|l|}{$\begin{array}{l}\text { The welfare economics of international migration has developed more-or-less independently of } \\
\text { the welfare economics of international trade and investment. Moreover each of the two topics } \\
\text { has been tackled with its own distinctive technical apparatus. In the present note it is shown that } \\
\text { a core of quite general propositions about the gains from international migration can be } \\
\text { deduced from the two leading gains-from-trade theorems. }\end{array}$} \\
\hline Notes & \\
\hline Genre & Journal Article \\
\hline URL & $\begin{array}{l}\text { https://koara.lib.keio.ac.jp/xoonips/modules/xoonips/detail.php?koara_id=AA00260492-1993000 } \\
\text { 1-0001 }\end{array}$ \\
\hline
\end{tabular}

慶應義塾大学学術情報リポジトリ(KOARA)に掲載されているコンテンツの著作権は、それぞれの著作者、学会または出版社/発行者に帰属し、その権利は著作権法によって 保護されています。引用にあたっては、著作権法を遵守してご利用ください。

The copyrights of content available on the KeiO Associated Repository of Academic resources (KOARA) belong to the respective authors, academic societies, or publishers/issuers, and these rights are protected by the Japanese Copyright Act. When quoting the content, please follow the Japanese copyright act. 


\title{
THE WELFARE GAINS FROM INTERNATIONAL MIGRATION
}

\author{
Murray C. KEMP*
}

Abstract: The welfare economics of international migration has developed more-or-less independently of the welfare economics of international trade and investment. Moreover each of the two topics has been tackled with its own distinctive technical apparatus. In the present note it is shown that a core of quite general propositions about the gains from international migration can be deduced from the two leading gains-from-trade theorems.

\section{INTRODUCTION}

The welfare economics of international migration has developed more-or-less independently of the welfare economics of international trade and investment. Why this has been so is not entirely clear; however part of the explanation may be found in the many non-economic motives for international migration and in the fact that migration often (but not always) involves the movement of both a factor and its owner.

Moreover each of the two topics has been tackled with its own distinctive technical apparatus. Whereas the gains from international trade and investment have typically been examined in terms of quite abstract general-equilibrium models, the gains from international migration have usually been analysed in terms of partial-equilibrium or simple $2 \times 2 \times 2$ general-equilibrium models.

In the present note it will be shown that a core of quite general propositions about the gains from international migration can be deduced from the two leading gains-from-trade theorems. Moreover the reader will be reminded that the gains-from-trade theorems are now known to be valid not only under the familiar assumptions of Arrow-Debreu general-equilibrium theory but also in the presence of incomplete markets, in a context of overlapping generations and infinite horizons, and in some types of monetary economies. Thus a strong link will be established between the welfare economics of international trade and the welfare economics of international migration, a link which holds firm over a very considerable domain. ${ }^{1}$

\footnotetext{
* The author is grateful to Koji Shimomura, Henry Wan, Kar-yiu Wong and a referee for their comments.

1 The link is already implicit in Ohyama (1972), where it is understood that the list of tradeable commodities includes primary and produced factors of production.
} 


\section{THE GAINS FROM INTERNATIONAL TRADE AND INVESTMENT}

The welfare economics of international trade contains two core propositions which are valid for countries of any size.

Proposition $\alpha$ (The Gainfulness of Trade for a Single Free-Trading Country). If some closed country s abandons all artificial obstacles to international trade, either in the whole set of potentially tradeable goods or in some proper subset, and if the preferences, technologies and endowments of the trading partners are suitably restricted then there is a scheme of lumpsum compensation in $s$ and an associated competitive world equilibrium such that no individual in sis worse off than in autarky.

Proposition $\beta$ (The Existence of Gainful Customs Unions). If an arbitrary world trading equilibrium is disturbed by the formation of a customs union comprising some subset of two of more countries then there exists a common external tariff vector, a scheme of lumpsum compensation, restricted to individuals in the union, and an associated world trading equilibrium in which (a) no individual, whether a member of the union or not, is worse off than before the union, and $(b)$ the net tariff revenue of the union is at least as large as the net compensation accruing to individual members of the union.

In both propositions, the list of tradeable goods may include primary and produced factors of production, including labour, as well as pure consumption goods.

Propositions $\alpha$ and $\beta$ are remarkable for their robustness to respecification of the economy. Originally demonstrated for a world of Arrow-Debreu economies [Kemp and Wan $(1972 ; 1976 ; 1986)]$ they are now known to be valid for economies with incomplete markests, for at least some types of monetary economies, and for economies with overlapping generations and infinite horizons [Kemp and Wong (1990a, b; 1991a, b)].

\section{THE GAINS FROM INTERNATIONAL MIGRATION}

$(\alpha)$ Suppose that the residents of a closed economy are presented with the opportunity to trade and invest internationally and with the opportunity to emigrate and/or to receive immigrants. Then Proposition $\alpha$ applies, provided that emigrants are included in the scheme of compensation and immigrants excluded. (Of course, the compensation of emigrants must be calculated on the basis of the country-of-origin consumption and prices.)

The fact that, in the case of labour migration, the owners move with the factor does not affect the applicability of the proposition, provided that the preferences of emigrants do not change with their country of residence. In particular, whether or not emigrants remit part of their earnings, to support their families or for investment, is of no theoretical significance. (Its administrative significance is 
another matter. After an emigrant's departure, and in the absence of remittances, it may be legally impossible to secure a contribution to a scheme of compensation. In that case, the migrant's departure may be made conditional upon the prior completion of the transfer).

What happens to the preferences of immigrants, on the other hand, has no bearing on the applicability of Proposition $\alpha$ (although it obviously affects the extent of the gains). Immigrants are merely foreign suppliers of labour, on a par with foreign exporters of any other commodity. The fact that they happen to consume their wages in the host country is of no significance.

Nor does it matter whether migration is permanent or temporary or, indeed, repeated or periodical. For each individual, and for each moment of time, compensation is so calculated that, if he were living in his country of origin, he could consume the bundle that he would have chosen under continued autarky. If for some part or parts of the interval convered by our analysis he chooses to reside in the country of destination, it is because he prefers to do so.

Nor does it matter if emigration and immigration take place simultaneously, even to the point where a country loses its entire initial or autarkic population. Compensation is always of the initial population, including emigrants but excluding immigrants, and on the basis of country-of-origin consumption and prices.

It might be though that non-traded consumption goods invalidate the above reasoning; but this is not so. Suppose that non-traded goods form part of the initial consumption bundle of an emigrant and that not all of those goods are produced in the country of destination. Then, after compensation, the migrant can purchase his initial bundle only if he returns to his country of origin. If he chooses to not return, however, he is revealed as preferring an attainable posttrade post-migration bundle to the initial bundle. Similar reasoning applies if the same non-traded goods are available in each country but at different relative prices.

Finally, nothing can be said about the change in wellbeing of an immigrant who is not part of a scheme of compensation in his country of origin. Of course, given the world equilibrium after the elimination of restrictions on trade and migration, an immigrant is revealed as preferring to live in his country of destination. But that reveals nothing about his ranking of the pre-trade situation in his country of origin and the post-trade situation in his country of destination.

Suppose alternatively that, initially, there is free trade in some goods but the world's frontiers are closed to migration. Subsequently, the front $\mathrm{rrs}^{-}$are opened. In effect, it is possible to trade in another commodity. Except in the uninteresting small-country case, one cannot be sure that, after compensation, a particular country will benefit from the enlarged trading opportunities. After the opening of the frontiers, however, the world enjoys a more efficient allocation of its resources. It follows that, for at least one country, there is a potential enhancement 
of welfare. $^{2}$

$(\beta)$ Turning to the interpretation of Proposition $\beta$, let us now suppose that a world equilibrium of international trade, investment and migration is disturbed by the formation, by some proper subset of countries, of a common market embracing produced commodities as well as primary factors of production like labour. Then Proposition $\beta$ applies, it being understood that the common vector of external tariffs may include a tax on migration between member and nonmember countries. ${ }^{3)}$ Thus if the tariff vector and the scheme of compensation are carefully calculated then all individuals initially in the common market, including those who choose to leave it, benefit from its formation.

If in the initial world equilibrium all factor movements are ruled out, one can imagine the formation of a common market as proceeding in two stages. In the first stage, a customs union, embracing produced commodities only, is formed; in the second stage, all restrictions on the intra-union movement of factors, including labour, are removed. If at each stage the common external tariff and the scheme of compensation are carefully chosen then at each stage all individual members of the union are made better off. This is in contrast to our earlier finding that the enlargement of the list of freely traded goods may harm some individuals and some countries. ${ }^{4}$ The present sharper result is made possible by the international character of compensation within the union.

\section{FINAL REMARKS}

In spite of appearances, none of the conclusions of Sec. 3 is inconsistent with the findings of the best recent treatments of our topic. Thus when Johnson (1967), Wong (1986), Quibria (1988) and Tu (1991) demonstrate that a country of origin cannot gain from migration they do so on the implicit assumption that emigrants are excluded from the scheme of compensation adopted by that country. ${ }^{5}$

On the other hand, when Wong (1986), Quibria (1988), Tu (1991) and Clarke and $\mathrm{Ng}(1991)$ rely on special models to demonstrate that the initial residents of a country of destination necessarily benefit from free trade and migration, they overlook the more general demonstration implicit in the stardard Proposition $\alpha$.

University of New South Wales

${ }^{2}$ Even this is not true if labour is the last on the list of goods (primary factors and products) to become mobile and if the same constant - returns technology is available to all countries. In that case, the mobility of labour leaves the world's allocation unchanged, and that is true whether the individual countries are large or small.

${ }^{3}$ From Lerner's symmetry theorem, one tariff can be arbitrarily chosen. In particular, the tax on migration might be set equal to zero (as in the European Economic Community).

${ }^{4}$ See the final paragraph of Sec. $3(\alpha)$.

5 Johnston (1967) and Wong (1986) consider the possibility that their conclusion may be reversed if the migrants leave behind a sufficient amount of their capital. However the capital remains the property of the migrants and continues to earn income for them. Hence the separation of the migrants from their capital cannot be interpreted as a compensatory transfer to those left behind. 


\section{REFERENCES}

Clarke, H. R. and Y.-K. Ng (1991), Are there valid economic grounds for restricting immigration?, Economic Papers, 10, 71-76.

Johnson, H. G. (1967), Some economic aspects of brain drain, Pakistan Development Review, 7, $397-409$.

Kemp, M. C. and H. Y. Wan (1972), The gains from free trade, International Economic Review, 13, $509-522$.

Kemp, M. C. and H. Y. Wan (1976), An elementary proposition concerning the formation of customs unions, Journal of International Economics, 6, 95-97.

Kemp, M. C. and H. Y. Wan (1986), The comparison of second-best equilibria, in D. Bös and C. Seidl, eds, Welfare Economics of the Second Best, Supplementum 5 of Zeischrift für Nationalökonomie, 161-167, Vienna: Springer-Verlag.

Kemp, M. C. and K.-Y. Wong (1990a), The gainis from trade when markets are possibly incomplete, University of Washington.

Kemp, M. C. and K.-Y. Wong (1990b), The gains from trade when markets are possibly incomplete: A more general analysis, University of Washington.

Kemp, M. C. and K.-Y. Wong (1991a), Gains from trade with overlapping generations, University of Washington.

Kemp, M. C. and K.-Y. Wong (1991b), Gains from trade for a monetary economy when markets are possibly incomplete, University of Washington.

Ohyama, M. (1974), Trade and Welfare in general equilibrium, Keio Economic Papers, 9, 37-73.

Quibria, M. G. (1988), On generalising the economic analysis of international migration: A note, Canadian Journal of Economics, 21, 874-876.

Tu, P. N. V. (1991), Migration: Gains or losses?, Economic Record, 67, 153-157.

Wong, K.-Y (1986), The economic analysis of international migration: A generalisation, Canadian Journal of Economics, 19, 357-362. 